\title{
Jour au Nuage
}

\author{
Jennifer Friesen
}

Sombre sans ombre c'est le temps des fantômes

Personne ne me voit

Dans ce parc calme et froid

Qu'une femme qui sent des fleurs

Et qui se bavarde.

Etre sans ailes et sans racines

Sans avenir, sans origines

Etre sans ailes et sans racines

Sans avenir, sans origines

Les fantômes sont glabres

Comme les salamandres blanches des cavernes

Ils me mordent les pieds

Ils me font danser.

rendez-vous

Regret

repoussant

The University of Kansas 